\title{
ПРАГМАТИЧНА ОРІЕНТАЦІЯ ПАРЕМІЙ У ХУДОЖНЬОМУ ТЕКСТІ
}

Колоїз Ж. В. Прагматична орієнтація паремій у художньому тексті.

У статті йдеться про паремії як одиниці з запрограмованим прагматичним ефектом, що виступають не лише репрезентантами типових ситуацій, але й сигналізують про експресивну атмосферу представленого художнього простору, максималізують його стилістичний ефект, сприяють реалізації тих чи тих авторських інтенцій, гармонізують прозовий текст, роблять його ритмічним, мелодійним.

Ключові слова: текст, паремія, прагматичний ефект, функція, звуковий повтор, лексичний повтор.

Колоиз Ж. В. Прагматична ориентация паремий в художественном тексте.

В статье идет речь о паремиях как единицах с запрограммированным прагматичным эффектом, которые выступают не только репрезентантами типичных ситуаций, но и сигнализируют об экспрессивной атмосфере представленного художественного пространства, максимализують его стилистический эффект, способствуют реализации тех или тех авторских интенций, гармонизуют прозаический текст, делают его ритмичным, мелодичным.

Ключевые слова: текст, паремия, прагматичный эффект, функция, звуковой повтор, лексический повтор.

Koloiz Zh. V. The pragmatic orientation of paremiological unit in the literary text.

The article deals with the paremiological units as units with programmed pragmatic effect that are not only representatives of typical situation and convey expressive atmosphere of literary text. They increase the stylistic effect and help to realize author's efforts. Also they harmonize prose text and make it more rhythmical and melodious.

Key words: text, paremiological unit, pragmatic effect, function, sound reiteration, lexical reiteration.

На сучасному етапі розвитку лінгвістичної науки не викликає заперечень те, що текст є продуктом мовленнєвої діяльності, яка становить сукупність мовленнєвих дій та мовленнєвих операцій 3 боку мовця, що продукує мовленнєвий акт, i слухача, який його сприймає (В. Бєлянін, С. Васильєв, О. Воробйова. А. Загнітко, О. Земська, О. Каменська, О. Кубрякова, Р. Попов, Т. Трегубович).

Письменник, творчо осмислюючи дійсність, об'єктивує свої думки у вербальній формі «для інших», перетворює зміст своєї індивідуальної свідомості в соціальний феномен - текст. Причому кожен раз він постає перед вибором між кількома альтернативно можливими вербальними засобами, за допомогою яких ця інформація може бути передана через відповідні канали. Його зусилля спрямовані на пошук таких 
комунікативних параметрів, які забезпечили б не абстрактний обмін інформацією, а той реальний процес спілкування, що складається 3 багатьох компонентів, до яких належать й інформативний зміст, і вплив на адресата, і контролювання його вчинків та почуттів.

Сила впливу залежить від особливостей оформлення запропонованої читачеві інформації, що стимулює пошук письменником відповідних художніх засобів відображення.

Немає сумнівів у тому, що паремії самі по собі характеризуються прагматичною орієнтацією, а в канві художнього макротексту використовуються не лише для впливу на адресата, а й для регуляції його поведінки, апелюють до емоційної сфери і через неї до інтелекту, їх використовують насамперед для інтелектуального переконання або для переконання через інформування. Будучи одиницями з запрограмованим прагматичним ефектом, вони формують прагматичний центр висловлювань, увиразнюють позитивну чи негативну оцінку створюваних автором ситуацій загалом. Наприклад: - Не страшна мені на другий світ дорога, спокутувала я гріхи свої, Бог простить. А страшно мені, дитино, погадати, що оставлю тебе самою, - казала Марія Федорівна. - Я не билина, тітусю, вітер не зломить мене. - Буря $\boldsymbol{i}$ дуба ламає, Мотре. Буря надходить, чує ухо моє. - Тишина перед бурею від самої бурі страшніша [3, с. 215]; Ніч і степ настроюють до таких розмов, тим паче, щуо шведи свої псалми співають. - Б'ються, як чорти, а моляться, як святі. - Такий народ. - Який король, такий народ [6, с. 144]; - Того я собі не бажаю і ані чинів, ні маєтностей не хочу, бо й того, щзо в мене є, для мене і для жінки досить. - Досить, та від прибутку голова не болить. - Як кого. Та не мене. Я за правду стою. А на мою гадку, правда ані по нашому бочі, ані по їх, лиш посередині [5, с. 455] тощо. Такі одиниці в художніх текстах найбілыш повно й абсолютно недвозначно віддзеркалюють суть ситуацій, становлять одне 3 невичерпних джерел посилення експресивності, поглиблення логізації викладу, відповідно, набувають особливої естетичної значущості.

Мета нашої статті - дослідити особливості використання «прагматично заряджених» пареміологічних одиниць у творчій спадщині Богдана Лепкого, з'ясувати їхні можливості та функціональностилістичне навантаження в художньому просторі історичних повістей.

Пенталогія Б. Лепкого «Мазепа» - соціальна панорама, де відображено не лише епоху, а й індивідуальні генетичні складники нації. Активним образотворчим чинником авторської оповіді $\epsilon$ насамперед «перлини народної мудрості», або пареміологічні одиниці, що органічно вплітаються в мову історичних повістей, розкривають передусім 
внутрішній світ, настрій, світогляд персонажів, створюють національний колорит, забезпечують ефект безпосереднього спілкування, формують «ядро фрагмента дискурсу» і задають «вектор оцінки ситуації відповідно до законів народного мовомислення» [8, с. 114]. Наприклад: - Карлова побіда - це визволення наше. Розум велить усіма способами помагати йому до побіди. Треба Дон прихилити до шведів і калмищького хана Люку з усіми його полчищами. Для нас щзе й тая користь, щзо кращзе їх зробити союзниками, ніж ворогами. - Борони мене, Боже, від приятелів, бо 3 ворогами сам собі дам раду, - завважив Апостол. - Пословиця не до кождого випадку підходить, - відповів на те гетьман. - I твоя тепер не годиться, бо на всі сторони воювати ніхто не може [5, с. 158]; Пробуйте! - а в душі додав: «Може, дійсно, свій свого краще зрозуміє, i пішов собі геть. - Гарна пісня, так співаки погані!» - подумав собі [6, с. 64]; - А ви, гадаєте, крамі? - відгризається тамтой $i$ затягує пісню, та таким-то голосом сильним і гарним, щ⿻о ніхто й не підтягає за ним, щзоб не псувати. - Співай щзе, - просять його. - До співу-то ти здатний. Пан Біг щз тобі з голови уймив, то у горло наддав. - А вам-то пан Біг не жалував язиків, - каже той, щчо його брали на кобеняк. - Вус тихо сиди, як бороду голять! [3, с. 64]. У подібних художніх контекстах паремії виступають своєрідним «комунікативними посланнями», оскільки еквівалентні і співвідносні із судженнями щодо тих чи тих життєвих ситуацій. Крім того, такі одиниці слугують своєрідним регулятором поведінки людини в суспільстві, є, так би мовити, «соціальною пам'яттю», де зберігається досвід нації, яким при нагоді можна скористатися, виступають «стилетворчим фактором, що характеризує загальну тональність дискурсу» [8, с. 114], увиразнюють художні тексти, актуалізують їхній емоційний та експресивний колорит, адже формують відповідне (позитивне / негативне) ставлення адресата до зображуваних подій, явищ, персонажів.

Проілюстровані паремії використовуються як ефективний засіб аргументації для підтвердження висловлених думок: письменник «розраховує» на те, що читач безапеляційно довірятиме паремійній мудрості, бо за кожною з паремій стоїть авторитет поколінь. Водночас, називаючи типові ситуації тим чи тим усталеним висловом, автор прикрашає i лаконізує мовлення своїх персонажів, робить його дотепним: - Не люблю я святого вечора. Чому? - Бо не дають обіду. За то вечеря добра. - Вдома крама. - Бо ти мамин син. - А тебе до дівчат тягне. - Що може не гарні иинкарки в Кочубеєвій корчмі на полтавськім шляху? - Кочубеєва донька краща. - Мудрагель! Краща троянда від ромену. Та, бач, зависокі пороги на намі ноги [4, с. 120]. 
Подекудидосягає ефекту безперервного, жвавого потоку уснорозмовного мовлення: - Як дивлюся на людські достатки, як вони $з$ жінками й дітьми у вигодах живуть, то такий мене жаль за серце стискає, щуо або їм кінець, або мені. - I чому б то багачам з бідними не поділиться? - Захотів молока від бика. - Попроси в жука меду. - У них і серед зими не випросиш леду. - Багач глухий, коли кажеш: дай, а скажи: на, то вчує. - Багача просити, щцо глухому пісню співати. Вмерлого не розбудиш, багача не допросишся, його не проси, а сам бери, щзо візьмеш, те й твоє [5, с. 58]; Лежачи по пісній вечері на подушках з недертого пір'я, нарікали на свою лиху долю. - Моя доля, як із собачого хвоста сито. - А мою, якби собака уздріла, то три дні до місяця вила б. - Не було зранку, не буде й до останку. - Недаром говорив мій покійник, скільки свічки, стільки й світла. Погас, та й пішло мені з Петрового дня. - Свосї недолі і конем не об'їдеш. - Так мало бути і так сталося. - Та коли б, чуєте, знаття, де впаду, то б $\boldsymbol{i}$ соломки підослала. - Коли б знаття, щчо в куми пиття, коли б той розум спереду, щзо ззаду. - I я ц̧е кажу, щуо коли б той розум спереду, щчо ззаду, то не їхали б [4, с. 20] тощо.

До того ж будь-яка паремія не лише називає, але й оцінює ситуацію з позицій народної етики. Оцінка тієї чи тієї ситуації з позицій народної мудрості сприймається як більш переконлива, ніж та оцінка, яка грунтується лише на особистому досвіді мовця. Відповідно, паремійна оцінка не піддається жодним сумнівам. У художньому мовленні важливим $є$ й те, що паремійна оцінка не тільки високо авторитетна, але й анонімна. Це особливо важливо, якщо врахувати те, що паремії позначають негативні ситуації значно частіше, ніж позитивні. Послуговуючись тією чи тією паремією письменник не лише апелює до незаперечного авторитету народної мудрості, але нібито знімає з себе відповідальність за обраний спосіб вираження. Наприклад: Гетьман на хвилину зупинився, Орлик слухав, до чого він веде. - Тому-то я й прошу тебе, щуоб секретно пойхав до Києва $i$ розвідався в митрополії, як вони там поставилися б до мого з Мотрею Кочубеївною подружества, тому бо вона мені хрещеницею доводиться. Ти служив писарем у Київькій митрополичій канщелярї, знаєш усі входи й виходи, і я тебе не потребую вчити, як братися до цзього тонкого діла, щуоб і вовк був ситий, $\boldsymbol{i}$ коза ціла [4, с. 154]; Якнайобережніме взяли й попрямували до двора. - Зрозумій їх! Казали істреблять усіх без розбору - хлопів і жінок, старих і дітвору. А тут під відповідальністю. - Бо паня. Не Матроша. Чув? - Всі вони руку за собою тягнуть, ті пани. - Крук крукові не виклює ока [5, с. 382]; - Де 
стріляли? Хто почав? Наші чи ворог? Москаль під охороною ночі переправився через Сейм $і$ здалеку обходив Батурин. Наші завважили це $і$ почали пальбу. Якогось московеького майора вбили. - Як здохне лис, то кури плачуть. - жартував диякон. - Лии даром не стріляйте, діти! Мушкет без куль і кочерги не вартий. Знов сміх [5, с. 326]. - Не все біблейні слова стукайте, а «отверзеться вам» справджуються $в$ життю. Європа не хоче, щоб Росія стала європейською державою. Небезпечно медведя у пасіку впускати [5, с. 96]. - Але ж вони на возі! - Бо сил не мають іти. - Так їх скатували, Боже ти мій! - На простім драбинястім возі їдуть, а перше їздли в золочених каретах. Байдуже ракові, в якім глеку його вариш [5, с. 181].

Паремії ситуативні, вони не тільки вживаються в конкретній ситуації, але й самі цю ситуацію моделюють чи означають. Замість довгого витлумачення ситуації такі усталені конструкції дають змогу описати іï одним реченням, наділяють іï потужним зображальновиражальним потенціалом.

Естетична функція паремій забезпечується належністю їх до народно-поетичного мовлення. Кожна паремія - це «художня мініатюра, що в яскравій, відшліфованій формі узагальнює (а точніше, моделює) факт самої дійсності [7, с. 14-15], тому паремійний текст (мікротекст) легко вирізняється в художньому мовленні (макротексті) своєю «ладністю і звучністю», фольклорним «ладом і складом». Це, так би мовити, готова поетична формула думки. Пор.: - Як звичайно, багато. 3 тої пори як на нас москалі нахлинули, від покривджених $і$ не обженешся. На послухання зголошуються мало щуо не самі такі, щзо перед кривдами московськими в гетьмані шукають оборония. - Що ж я їм поможу? Царська воля сильніша від мене. - Це не воля, а сваволя, сказав Орлик. - Мовчи, язичку, будеш їсти кашку, - погрозив йому гетьман [3, с. 48]; «А щзо ж Станіслав переказує мені?»- спитав гетьман. "I питати не треба. Потопаючому і бритва пором. Станіслав згідний піти назустріч бажанням вашої вельможності, бо мусить. Годиться навіть на те, щчоб гваранцію король Карло підписав» [5, с. 96]; - Я того слова не скажу, хоч як мені важко, Бог один знає, як важко мені кидати тебе, Іване Степановичу. - Не тяжче, ніж мені оставатися без тебе. Посумніють мури і пусткою повіс по хаті. Краще не приїздиа б була, Мотре. - Коли б знаття, як краще! Чоловік собі не ворог, а потопаючому і соломинка спасіння [4, с. 176]. Відтак інформативна функція тієї чи тієї паремії завжди супроводжується естетичною: послуговуючись усталеним висловом, письменник не лише називає типову ситуацію, але й характеризує, оцінює іiі. У такому

๑ ж. В. Колоїз, 2013. 
раз паремію можна кваліфікувати як яскравий художньо-виражальний, прагматично орієнтований засіб.

Прагматична орієнтація паремій великою мірою завдячує «образності», що досить яскраво простежується на тлі нейтральних контекстів i яка, у свою чергу, забезпечується стилістичними засобами, наявними в образній структурі висловів.

Ефект впливу на адресата досягається прередусім за допомогою евфонічних засобів, засвідчених у структурі паремії, 3-поміж яких вирізняються римовані співзвуччя, алітерація, асонанс, що забезпечують ритмомелодику паремійних мікротекстів, яка сприяє їх кращому сприйняттю і як результат - запам’ ятовуванню [1, с. 250].

У комунікативний простір історичних повістей Богдан Лепкий доволі часто «вплітає» так звані римовані паремії, у яких простежується суголосся закінчень у суміжних чи близько розташованих словах: Милосте ваша! Не журіться. Ваш розум, а наші руки, - не підемо в Москву иукати науки [3, с. 11]; -Гадаєте, щуо ніхто з ваиих не запопадає ї̈. Гадаєте, щзо ие все ваші приятелі? - $і$ він рукою показав на гетьманських стариин. - Це такі приятелі, щзо з ними дружси, а ніжс під полою держси. От щуо! Це я вам по прихильності до вамої світлой особи кажу, а не з іншої причини [3, с. 22]; - Навіть на запорозьких землях розплоджувалися ватаги всіляких гультіпак, щуо, кинувии свої

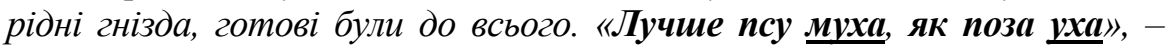
казали, пускаючися на непевне діло [5, с. 55]. Рима й інші звукові механізми роблять подібні вислови ритмічно стислими, відшліфованими, що сприяє художній довершеності не тільки самих конструкцій, але й художніх контекстів загалом.

Ритмомелодика паремій, якими послуговується письменник, є неоднаковими за своїми характеристиками, зокрема щодо якості співзвуч, частиномовної належності, повноти суголось, щодо розташування і т. ін., як-от: - Не раз бував я у важких пригодах, але в такій, як тепер, не був. Тут або пан, або пропав. Прийдеться все ставити на одну карту. Я азартної гри не хотів. Досить вже гараздували мої попередники [3, с. 62]; - Нема за щуо, нічого доброго я тобі не сказав і нічого певного. Може, колись другим разом, як зайдеш до мене. Хто любить ревно, той жсаліє певно [3, с. 81]; $A$ на третьому полі - жіночка-молодччка, повновида, круглоличка, хоч води до неї напийся, така миленька, така солоденька, ніби цуо лиш з церкви після святого причастя вернула, тягне свого сутуловатого подруга за вус та щуе й лівою рукою у потилицюю итовхає, щзоби з иинку додому поспішався. А тут знову надпис: "Жінка поти пюба, поки не візьме за 
$\underline{\text { цуба } » ~[3, ~ с . ~ 108] ; ~ « С п о к і и ̆ н і ~ б у д ь т е, ~ т і т у с ю ! ~ Б е з с л і д н о ~ з і ~ с в і т у ~ н е ~ з і и ̆ д у . ~}$ Не знаю, які ті сліди остануться за мною, але я чую, щзо по хмарах не ходжу. Я не метелик і не птаха, тето, я людина, дивна й химерна, але людина!» «Яке ж те життя, без мужа і дітей? Досить одної сивої коси в роді». «Може, й мені доведеться посивіти зарання - га, щуо ж велике діло! Що там тіло, щцоб серце не зміліло» [5, с. 40]; Любов Федорівна питалася гетьмана, чого їм тепер сподіватися, миру чи дальшої війни. - Жоди біди від води; а горя від моря, - відповів гетьман. - Мира ще й не видати. Мабуть, війна щолиш розгорюється. Боюся, щоби той пожар не обхопив і нашої хати. Польща $і$ Росія, сакси, датчани і шведи, а з полудня турки - такої війни вже давно не бувало [3, с. 138]; - Про наші маєтки, - казала Кочубеїха, - люди казки розказують, а вони то й не такі вже великі, як вони собі гадають. У гетьмана куди більше гроша. - На те він і гетьман, - перебив ї̈ муж. Більший пан - кращий крам [3, с. 95].

Наведені контексти репрезентують паремії, які яскраво ілюструють бідні / багаті (перші характеризуються якомога більшою кількістю співзвуч у словах, що належать переважно до різних граматичних категорій (юба - yбa), у других - майже відсутнє суголосся (무 $-\underline{n p o n a \beta})$, граматичні / неграматичні (у першому разі римуються слова однієї частини мови (евно - певно; горя - моря), в

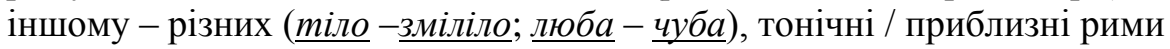
(у першій збігаються всі звуки після наголошеного в римованих

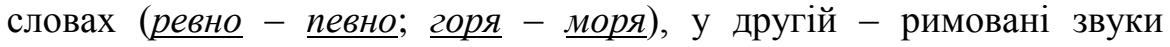

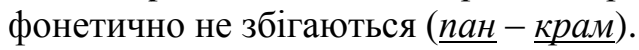

Народні вислови доволі часто ілюструють дієслівні рими: Того дня підвечір миргородчеві захромав кінь. Це дало притоку для нових жартів. - Добрий кінь, - казали козаки, - день біжнть, а три дні лежить. - То така кобила, - жартували другі, - що море перескочить, а хвоста не замочить. Ти ї сховай, як сотником станеш, то на ній дальше поїдеш. Може, нею і пірнача доскочиш [3, с. 77], подекуди неточні: - Пан Біг гнівається за кров, - сказав хтось. - Людська кровиця не водиця, проливати не годиться. А невже ми ї̈ проливали? - Відома річ - не ми, а все-таки поплила. - Бог змиє. - Бог простить, бо не наша вина [3, с. 73] (пор.: кровичя - водичя - годиться); Кочубей птичка невеличка, каже, $i$ так воно є, Кочубей дійсно птичка невеличка, але Кочубейха - велика $i$ рідка птиия. Чорт сім пар постолів стоптав, поки ӥх докупи зібрав. Чого йому не достає, те вона додає. Кажуть, щчо жінка, як торба, щуо положии, те й несе. Та не Кочубеїха. В Кочубеїв якраз навпаки, вона кладе, а він двигає. Колись вона на нього понад сили наложить, $і$ він ๔ Ж. В. Колоїз, 2013. 
надсадиться [3, с. 45] (пор.: стоптав - зібрав). Хоч ця неточність не помічається в мовленні, оскільки вона компенсується змістом та словесною образністю. Навіть паремії з кволими дієслівними римами можуть мати сильні образи, які поглинають усю увагу читача. Аналогічним прагматичним зарядом вирізняються й пареміі, у яких римуються власні імена: - До митрополита у Львові посилати не раджу. Він чоловік непевний. Ще вас католицьким миром намастить. Краще католищьке, ніж жадне. - А мені здається, що краще підіждати, аж вернете в Київ. - Підіжди, Іване, ажс приложу гірчиці до рани [5, с. 18]; В ией мент увійшов гетьман, а рівночасно другими дверима вступив у світлицюю Апостол, котрий якраз тепер приӥхав. - Не роби, Даниле, ще тобі не миле, - кликав гетьман, ідучи йому назустріч. - Що ж такого не маю я робити? - питався гість. - Пізно приїздити. Ми вже гадали, щчо й не побачимо тебе нині [4, с. 161].

Іноді у прислів'ях, навпаки, рими бувають доволі точні й виразно змістовні, що навіть самі по собі без контексту здатні психологічно насторожувати, викликати найрізноманітніші асоціації. Наприклад: - По чариі, по чариі та вп'ять по п'ять, - промовив Кочубей, але Чуйкевич, приймаючи чарку з його рук, просив, щьоб це була остання, бо йому вже куриться з чуба. - Який же ти козак, та ще військовий канцелярист біля самого гетьмана? Один сором, та й годі! Зводиться козаџький рід, марніс. Але що ж? На милування нема силування. Не хочеш, так $i$ силувати не стану, але й сам пити не буду, бо я не пияк [3, с. 111]; Боже ти мій! - кричав суддя, підскакуючи на подушках за кождим разом, як колеса перевалювалися через грубе коріння, щз, ніби велетенські гадюки, повилазило з нор на дорогу і вигрівалося до сония. - Боже ти мій! Як колись любив лови! А нині? Коли б не гетьманська гостина, найрадніше сидів би в хаті. - На кождий вік буває свій лік, - відповів Чуйкевич. - А на мій вік найкраший лік - відпочинок. Так відпочивати не дають [3, с. 110]; - Діло, котре робить король Карло, переживе його і його нащадків. Шведський народ малий, але він перетриває велику завірюху... Невже ж тільки ми не маємо такої віри, Пилипе? - Я вірю вамій милості, - відповів Орлик. - Вір собі і ділу. - Важко якось. Дуже скрутні часи. - Неважкко жнти в погоду, але перетривай негоду! [3, с. 203]; Остасться Орлик. На нього вся надія. Орлик один може рятувати справу. Найкраще, коли б так залишився й надальше генеральним писарем, а булаву щоб перебрав Войнаровський. Так була б покладена основа дідичної влади, а не припадкового вибору. Бо ніщо не дає такої нагоди до безладдя, сварок $і$ непорозумінь, як вибір гетьмана. I ніколи сусіди не мають такої змоги сунути свого носа до нашого проса, як 
власне тодi [6 с. 234]; Нараз коляса так високо підскочила, щзо пан генеральний суддя мало не вилетів з неї і мало йому соболева шапка 3 голови не злетіла. - Гов! - гукнув на візника, - кості мені розтрясеш, стій! Я злажу. Спинився віз, спинив свого коня Чуйкевич, $і$ Кочубей, піддержуваний чурою, виліз з коляси. - Гу! - сказав, обтираючи хустиною лище. - Не привик ліс до панських коліс, нічого не порадиш! [3, с. 110]; - Послухай його маніхвестів, поможи побити царя, то він панів польських накличе на нас, закріпостить народ. - Буде щц лан, то

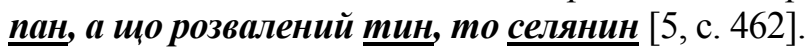

Приблизне римування ілюструють не лише слова з частиномовним значенням «предметність - процесуальність», а й зі значенням «предметність - атрибутивність» і навіть ті, що належать до одного лексико-гаматичного розряду. Пор.: Першу чарку піднесла хазяйка його милості гетьманові. - От тут-то й годиться пошанувати наш предківський звичай, - сказав гетьман, натякаючи на те, щуоб Кочубейха пригубилася до чарки. Вона це $i$ зробила. Але гетьман $i$ тим не вдоволився: - Хто не вип'є до дна, - казав, - той не мислить добра [3, с. 136]; Ніч і степ настроюють до таких розмов, тим паче, щуо шведи свої псалми співають. - Б'ються, як чорти, а моляться, як святі. Такий народ. - Який король, такий народ [6, с.144]; Ні на хвилину не сумнівалися, щуо побіда по їхньому бочі. Будували свій донос не на брехні, а на словах самого гетьмана, забуваючи, що verba volant, seripta mament. Гетьман мав сильніші докази невинності, бо закріплені чорнилом на папері, а щио напишеш пером, того не витягнеш волом [5, с. 109]; От як москалі вміють секретні ради тримати! - завважив хтось. - То правда, а ми свобідний народ і не любимо секретів. Що на сериі, те й на язиці. - Біжимо з язиками, чи треба, чи не треба [5, с. 6].

Ефективність закодованої інформації в тій чи тій комунікативно-прагматичній ситуації загалом і в пареміях зокрема забезпечується й місцем ритмічного акценту в суголосних словах. Особливої сили й експресії надають римованим пареміям так звані чоловічі, або окситонні, рими, коли наголос падає на останній склад: Чому ж то, дядьку, Великдень кращий від Різдва? - питався Войнаровський. - А тому, бачиш, бо на Великдень усі иүілуються, а на Різдво ні. - Голодній кумі хліб на умі, - сказала, всміхаючись, тітка Лідія [4, с. 128]; Коли який півмисок підходив до Апостола, то він, як сват, не відпрошувався, тільки накладав на тарілку своєї сусідки $i$ свого сусіда зліва, а тоді і на свою та приговорював: - От тут тії сидять, щуо добре їдять! Накладаючи на тарілку Марії Федорівни, він за кожним разом кликав: “Щуми до күми!» - i Марія Федорівна ๑ ж. В. Колоїз, 2013. 
всміхалася, дивлячись на його бадьоре обличчя [3, с. 137]; -Перейдемо разом, а як ні, то й залишити в якомусь городі, подальше від воєнного пожару. Та об тім ми ще побалакаємо з Іваном Степановичем. Він голова. - Авжеж, щуо не хвіст, такий, як Кочубей. - Гей-гей, Кочубей! - промовив Горленко і зітхнув. - Такий богатир, такий пан і під кнут спину наставив. - Бо дурний. Жінці потурав. - Жінку люби, та ум не губи [5, с. 143]; Поснідавши та розплативщись з иинкаркою $i$ розпрощявшись $з$ нею $i$ з ї гарними доньками, сів на коня. Випровадили його аж на вулицю і показали коротшу дорогу. - Їдьте 3 Богом у добрий цас та з поворотом не минайте нас [3, с. 81].

Жіноча, або парокситонна, рима сприяє уповільненому, мелодійнішому звучанню, оскільки акцент знаходиться на передостанньому складі, що надає пареміям співучості: Жінки не лагодили сварок, тільки збільшували лемент. До своїх чоловіків приставали, щуо вони тупоумні, лінюхи, гевали, щуо не пильнують діла. Біда тобі, воле, як тебе корова коле [6, с. 221]; Гетьман ухопив карлика за вухо $i$ притягнув його до себе: - Chodzpantu, panietaskawy! Doustugwaszejhercogskiejmosci. - Кажи, але не бреши, знаєш щз про Кочубея? - Моя хата скраю, я нічого не знаю. - А чому ж щось таке верзеш, ні в кут ні в двері? - Ні в кут ні в двері, але саме там, де треба... Уважай, Мазепа, щуоб не вийшла халепа. I хіхікаючи, вихопився $з$ гетьманської руки, шульгнув під стіл, з-під стола поза велику кафлеву піч і в двері [3, с. 44]; - Безголов'я. ніхто нами не піклується. Ворог нас, як рибу в сак, загорне і ніхто навіть пальцем не кивне. - Тоді любить $\boldsymbol{i}$ сват, коли добре мається брат. - А коли бідний, то забуде брат рідний. - забігали в нас ласки, як були в добрі, а тепер - промишляйте самі. - Воно так: не лижи мені губ, як солодкі, а як гіркі, - солодкі я собі сам оближу [6, с. 221]. Рими цементують прислів'я в одне ціле, допомагають підкреслити паралелізм частин, зіставити значення, включені в римовані слова.

Задля посилення інтонаційної виразності подекуди використовуються паремії, що демонструють такі стилістичні явища, як алітерація (повторення приголосних звуків) та асонанс (співзвуччя наголошених голосних), які емоційно поглиблюють їх змістовий зв’язок, дають змогу сприйняти на слух емоційні ознаки, відчути «Пластику слова, його евфонію» (М. Пазяк): - Було колись, - отвітував гетьман, -минулося. Правда, Апостоле? Тепер нам інші таниі на умі. Правда. А все ж таки розібрало мене, мов вовка опеньки, а сорочки, бачиться, навіть прати не треба, така мокра. - Жаль дуже, щзо пан гетьман не бачив, як наш сотник польонеса йшов. - Я, - озвався, 
підморгуючи, сотник, - по-иляхецьки: гуляй, душа, без контуша, шукай пана без жупана [3, с. 146] (повторення наголошеного [а]: гуля́й душа́ - кунтуша́ - шука́й - па́на - жупана, ненаголошеного [у]: гуляй душа - контуша - жупана); - Нині Порта за нами стоїть. сераскир гострий наказ дістав, щуоб нікому волос з голови не спав, бо за це «зелений шнурочок» чекає. Але нам треба знати, щзо завтра буде, чи шведи підуть з нами, чи покинуть нас серед дороги? Перше тим турбувався мій дядько, тепер на мене черга. - А Орлик від чого? спохопливо спитала Ганна. - Ганночко! Брат собі рад, а сестра собі несла [6, с.175] (повторення наголошених [а]: бра́m - рád - сестрá несла́, [i]: собí - собі́; ненаголошеного [о]). Алітерація шиплячих у першому разі та сонорних у другому підкреслює звучання окремих слів, надаючи їм специфічного навантаження. Особливий художній ефект досягається при сполученні алітерації з асонансами, що створює ефект милозвучності, співучості.

До того ж письменник доволі часто за зразком таких народних паремій продукує афористичні вислови. Пор.: За ним і другі піднімалися, та не всякому воно приходилося легко. Хто пив пиво, тримався на диво, хто горівку, дивився у долівку, а хто мід, того тягло підспід, бо мід у ноги йде. Хто ж вірно служив божкові Пріяпу, уподобнявся цуапу, шукав тільки зачіпки, щьоб стати чоло до чола зі своӥм противником. Але ці останні мусіли покоритися перед звичаєм, щчо, де гетьман двором стоїть, там не смій починати бійки, бо за ие кара, $і$ то немала [3, с. 143]; - Та до чого ти це балакаєш? - перебила йому жінка. - Дай докінчити, тоді й побачии, до чого. - Та як же таку дурнищю при чужім козаку говорити, він, певно, вже і без тебе чув. - Ні, ваша милосте, про козу $і$ лозу я ще не чув, - заперечив Чуйкевич. - О, бачиш, - втішився Кочубей, - він ще не чув, так слухай тоді. Дере коза лозу, а вовк козу, а вовка мужик, а мужика пан, а пана юриста, а юриста дідьків триста, а нашого брата дере жінка кирпата, жіночка люба та дере за чуба... го-го-го!.. Бачии, до чого я казав? [3, с. 98].

У репрезентованих вище ілюстраціях спостерігається й прийом паронімічної атракції, грунтований на семантичному зближенні в контексті слів, псевдоморфеми яких позбавлені об'єктивної генетичної та словотвірної спорідненості. Звуковий повтор послідовно починає характеризувати слова як смислові одиниці тексту. Близькість фонетичних обрисів зумовлює співвіднесення слів як смислових одиниць і виникнення між ними різних семантичних зв'язків. Звукова атракція сприяє виокремленню додаткового значення звукоряду. Пор.: Мазепа поклав йому руку на коліно $i$, 
вдивляючися в очі, говорив ніби з жалем: - Женився би, так вороги не дають. Завидують щастя, кажуть, досить з тебе булави, а дівчину не лови, другому остав [4, с. 89]; I не окрилося від бистрих козащьких очей також те, що гетьман нібито дуже живо розбалакував 3 Кочубеєм і його дружиною, а між тим раз у раз позирав на Мотрю або пестив своєю тонкою рукою тую троянду, щуо лежала перед його тарілкою - троянду від неї. «Що воно таке? Невже би?.. Та ні, куди, куди! Це ж не рівня, до того вона хрещуениця його», - $i$ Чуйкевич чарку підносив до уст. - Горілочка, як дівочка, - казав до нього сусід, - як не п'єш до ладу, то зведе на біду [3, с. 137];-- Отся чисто як Кочубеїха, - казав полковник Скоропадський, показуючи свою тарілку сусідові з правої руки. - Пізнати з мови, якої хто голови, відповів Кочубей, зачувши слова, трохи заголосно вимовлені [3, с. 17].

Крім так званих звукових повторів, до виразних стилістичних засобів, що так чи так посилюють прагматичну значущість і самої паремії і художнього тексту загалом, належить і лексичний повтор, який забезпечує емоційну тональність висловлювання і на якому подекуди грунтується ритміко-синтаксичний паралелізм. Наприклад: «Недаром, гадала собі Кочубеїха, - Апостол останніми часами так дуже за Мазепою тягнув. Не можна було лихого слова про нього сказати. Тепер гетьман бере його під свою протекиію. Рука руку миє». Лиха була на сина, щуо до Апостолів пристав. Батька-маму лишив [5, с. 106]; - Чув ти, Іване Степановичу, який я скупий. Кажуть, щзо я циикель ношу в кишені $i$, як прислуга не бачить, міряю ним хліб після обіду, а перед вечерею перемірюю, чи не вкрали. Га, га, га! Хай кажуть, не зашкодить. У нас $i$ так злодій на злодію їде і злодієм поганяє [3, с. 17]; - Хилю, хилю, - не тече, коло серця пече, - відповів! Чуйкевич. - На те ми й молоді, товаришу, щуоб нас пекло, як остаріємося, то зробиться зимно, не поможе й вино, як буде студено [3, с. 137]; - Хто ї̈ не перетягав, бажаючи чогось великого? Без великих жертв нема великого діла. Затям собі ті слова старого чоловіка. Наші старшини хотіли б отак собі «хитро, мудро, невеликим кочтом» [3, с. 202]; - Кождий за себе відповість, бо на те у нас розум і вольна воля є. Якщо цุарська власть від Бога, то гетьманська теж від нього. Гетьмана вибрав народ, а голос народу - голос Бога. Не гідні ми зватися людьми вольними, коли не розумісмо того [5, с. 458]. 3 погляду структурної організації у таких пареміях простежується чи то контактний, чи то дистантний лексичний повтор. Причому останній стосується як повторення відповідної одиниці (ii структурного елемента) 3 конотаціями, які доповнюють чи розширюють їі зміст (Гетьман заспокоӥв його, щуо тут иеркві нема чого 
міматися, а в душі погадав собі, щзо Кочубеї вже $i$ тую стежку топчуть. Пустили млин на всі заставки. Довідавшись від гостя, що йому треба було, налив ще чарку вина. - Спасибі! Боюся більше пити. Не бійтеся. Добра голова доброго вина не боїться. - Але забагато доброго, то також не добре [4, с. 159]; - Я Андрій Кандиба, - бубонів ией, - канцелярист гетьманської канцелярії у Батурині. - Чорнильна душа, як чорнильниця, чорна [5, с. 299]), так і повторення мовної одиниці на початку й у кінці паремії (Скрипіло Орликове вправне перо. Гетьман глядів крізь вікно. Табір шумів. Він мав свої турботи - харчі, горілка, чоботи і білизна. Турбувався малим. Великому - $\boldsymbol{i}$ турбота велика. У високе дерево громи б’ють [5, с. 228]; -Турки не крадучі люди, але $\epsilon$ тут $i$ наші народи, лихий його зна, які. - Бе-ре-жись, бо береженого і Бог береже, - відрубав Мручко [6, с. 164] (пор.: «Не тільки тут, скрізь так у політиці буває». «Але тут більще, як скрізь. Щось вони ніби зачувають свойм носом, та на слід попасти не можуть. На всякий спосіб, стереженого Бог стереже» [5, с. 23]).

Актуалізації уваги сприяє й так званий ланцюжок повторів, коли одна й та ж лексема наявна в різних мовленнєвих ситуаціях, що функціонують як єдине комунікативне ціле. Такі ситуації зазвичай протиставляються: - Бачу, що через мене ти маєш нові турботи, а тобі i давніх досить. Догадуюся, з чим мати вчора приїздла. Не вгнеш ти ї̈, Іване Степановичу, хіба зломиш. Але ломати не схочеш, бо це моя мати. Я розумію тебе і власне тому не бачу іншої стежки з того зачарованого круга, як покинути тебе. Сказала ие так спокійно $і$ таким звичайним голосом, щзо йому прикро зробилося на сериі. - Видно, не любиш ти мене, коли покинути бажаєш. - Не люблю самолюбною любов'ю. Велика любов до великої жертви спосібна, а велике діло великої любові вимагає [4, с. 174] (пор.: велика любов - велика жертва-велике діло велика любов). У такому разі простежується функція акцентуації комунікативно значущих елементів, що дуже тісно пов'язана з функцією актуалізації уваги, оскільки виокремлюються найбільш істотні характеристики, які в образній формі отримує адресат.

Прагматично зорієнтованими є низка повторюваних паремій, що використовуються для означення типових ситуацій у межах одного макротексту (Все воно переконувало його $і$ впевняло, щзо наближається рімаючий момент, рімаючий, не лиш для нього $і$ для Украйни, але, мабуть, для історії иілого Сходу. Тендітна сітка, котру він так хитро й обережно сплітав, доснована до решти. Треба вважати, щзоб ї̈ не порвали. Кінець діло хвалить, - треба подбати, щоб кінець не обезславив діла [5, с. 20]; Стариини гетьмана за ноги обіймали. ๑ ж. В. Колоїз, 2013. 
Батьку ти наш. спасителю наш добрий! По руках цілувати хотіли. Один другого обіймав. - Не лобзачіє ти дам, яко Юда, - казав Апостол, хлипаючи в гетьманових обіймах. - Воскресенія день, $і$ возвеселимся людіє, - прочитував Зеленський. - Кінець діло хвалить, - втихомирював їх гетьман. - А ие лиш початок, хоч і добрий. Подбайте ж, щэоб і кінець був гарний [5, с. 158]), а то й творчого доробку загалом (- Того ви не бійтеся, - заспокоював Мотрю мельник. - Ваші люди заячим слідом походили. Вас шукатимуть від Батурина на північ, а мій млин куди на полуднє. Де кум, де коровай! Але якщо ви неспокійні, то й поїдемо під вечір. Хай трохи коні спічнуть. Тепер темніється скоро. Гадаю сховати вас в одного старенького панотия [3, с. 235]; «I збіжжя, славити Бога, гарні. Кажуть, давно не було такого врожаю», - додала Марія Федорівна. "Де кум, де коровай. Куди там жнива, тітусю! Ще й весняні бурі не прошуміли» [5, с. 38]; - Від алкоголю, смію зауважити, - казав Меншиков, - підноситься температура. - Як у кого, а в мене клин клином вибивають, наливай, Іване Степановичу [3, с. 16]; - Кочубей новий донос до царя післав. - Певно? - Як Бог на небі. Царевичеві ией донос доставив, а ияаревич батькові переслав. - То недобре. - I я так гадаю. - Що робити? - Клин клином вибивають. - Себто? - Післати лист до ияая, щзо Кочубей інтригу між гетьманом $і$ цуарем затіяв, маючи на гадиі розбити їх дійствія воєнні совокупнії [5, с. 95]).

Повторювані паремії в інваріантній чи варіантній формі (пор.: «Чеши дідька зрідка, він і так кострубатий. Чує серие моє, щзо між нами ще до великого дійде. Він мені ногу підставляє. Котрийсь із нас конечно спотикнеться і впаде...» [5, с. 19]; - Цар стиснутий з ріжних боків, попросить Карла про мир. - I підпише пункти, які він подиктує. - Поки підпише, - завважив гетьман, - треба написати до нього. Годиться привітати царя з днем Петра святого, ие тезоіменство його. Побажаємо йому вікторії і таке друге. - Чеши дідька зрідка [5, с. 159]) посилюють прагматичний ефект. Повторення типових ситуацій, репрезентованих однією і тією ж паремією, виконує роль додаткової акцентуації.

Попри те, що народні афоризми кваліфікують як поліфункціональні одиниці, здатні узагальнювати, увиразнювати, оцінювати, виховувати, повчати, акумулювати i т. ін., не викликає жодних заперечень твердження: у художньому мовленні вони є прагматично орієнтованими, використовуються передовсім задля впливу на читача, актуалізації його уваги та моделювання його поведінки.

Паремії виступають не лише репрезентантами типових ситуацій, але й сигналізують про експресивну атмосферу комунікативних 
ситуацій, максималізують їхній стилістичний ефект, задають спрямованість прагматично значущої інформації, актуалізують найбільш важливі для адресата смислові ланки. Їх використання в художньому мовленні є потужним зображально-виражальним засобом, що сприяє реалізації тих чи тих авторських інтенцій, а особлива побудова деяких iз них, зокрема тих, які передбачають у своїй структурі різні повтори (передусім фонетичні і лексичні), гармонізує прозовий текст, робить його ритмічним, милозвучним, мелодійним, що загалом посилює прагматичний ефект.

\section{Література}

1. Алефиренко Н. Ф. Фразеология и паремиология : [учеб. пособ. для бакалав. ур. фил. образ.] / Н. Ф. Алефиренко, Н. Н. Семененко. - М. : Флинта: Наука, 2009. - 344 с.

2. Колоїз Ж. В. Українська пареміологія [навч. посіб. для студ. філол. спец. вищ. навч. закл.] / Колоїз Ж. В., Малюга Н. М., Шарманова Н. М. ; за ред. Ж. В. Колоїз. - Кривий Ріг : ТО «ЦЕНТР-ПРИНТ», 2012. - 349 с.

3. Лепкий Б. Вибрані твори : у 3-х т. Т. 1 : Мотря : [історична повість] / Богдан Лепкий ; Упорядн. Б. І. Мельничук; вступна стаття Н. І. Білик, Б. І. Мельничук. Тернопіль : Збруч, 2004. -350 с.

4. Лепкий Б. Вибрані твори : у 3-х т. Т. 2 : Мотря : [історична повість] / Богдан Лепкий ; Упорядн. Б. І. Мельничук. - Тернопіль : Збруч, 2006. - 399 с.

5. Лепкий Б. Вибрані твори : у 3-х т. Т. 3 : Не вбивай. Батурин : [історичні повісті] / Богдан Лепкий. - Тернопіль : Збруч, 2008. - 487 с.

6. Лепкий Б. С. 3-під Полтави до Бендер : [історична повість] / Богдан Лепкий. К. : Дніпро, 1992. - 266 с.

7. Пермяков Г. Л. Основы структурной паремиологии / Г. Л. Пермяков.- М. : Наука, 1988. - 224 c.

8. Семененко Н. Н. Русские паремии : функции, семантика, прагматика : [монография] / Н. Н. Семененко. - Старый Оскол : Изд-во РОСА, 2011. - 355 с.

Стаття надійшла до редакції 18.11.2013 p. 